\title{
MENGEMBANGKAN SKILL MENGAJAR (TEACHING SKILL) MAHASISWA CALON GURU MENGGUNAKAN MULTY STRATEGIES
}

\author{
Lufri, Sudirman, Silvi Rahmi \\ Jurusan Biologi FMIPA Universitas Negeri Padang \\ Korespondensi: Jln. Elang No. 1 Air Tawar Barat, Padang, Sumatera Barat \\ e-mail: lufri_unp@yahoo.com
}

\begin{abstract}
This study was aimed at improving the quality of learning process of Strategi Pembelajaran Biologi subject and in turn teachers with good pedagogic competence and teaching skill can be realized. Learning syntax that was carried out in this subject was: (1) course orientation and pretest administration, (2) learning process employing multi-strategy (concept approach, modeling and drilling method), (3) explanation and lesson plan design exercise, and peer teaching practices based on the lesson plan. The lesson plans were assessed by using IPKG-1 and teaching practices were assessed by IPKG-2, and (4) posttest was assessed IPKG-2 to figure out the improvement on the students teaching skill. The findings showed that there was significant improvement upon the students teaching skill in teaching practices by using multi-strategy.
\end{abstract}

Kata kunci: skill mengajar, mahasiswa calon guru, multy strategy

\section{PENDAHULUAN}

$\mathrm{K}$ enyataan yang terjadi di lapangan selama ini, pembelajaran Pembelajaran Biologi didominasi oleh metode konvensional, yang dikenal dengan metode ceramah. Sesungguhnya, mahasiswa kurang setuju metode ini mendominasi proses pembelajaran. Hal ini terlihat dari hasil survey yang penulis lakukan pada Semester Juli-Desember 2006 terhadap mahasiswa yang mengambil mata kuliah Strategi Pembelajaran Biologi. Sebagian besar (86\%) dari 38 orang mahsiswa berpendapat bahwa mata kuliah Strategi Pembelajaran Biologi tidak cocok lagi didominasi oleh metode ceramah. Alasan yang mereka kemukakan adalah bahwa mata kuliah ini sangat strategis dan sangat penting untuk mengembangkan kompe- tensi pedagogik, termasuk dan skill mengajar. Selanjutnya, mereka menyatakan bila pembelajaran konvensional masih tetap dipertahankan akan menghasilkan guru-guru yang tidak mampu memenuhi tuntutan dunia pendidikan atau tidak akan mampu meningkatkan mutu pendidikan di sekolah.

Di samping itu, 88\% mahasiswa menyatakan bahwa materi mata kuliah Strategi Pembelajaran Biologi tidak cukup hanya berupa teori saja, yaitu yang memuat berbagai teori tentang strategi, pendekatan, metode, model pembelajaran, kemampuan dasar guru, dan sebagainya tetapi harus dilengkapi dengan latihan (drill) untuk menghasilkan calon guru yang skill di lapangan. Pernyataan mahasiswa ini juga diperkuat oleh hasil wawancara penulis pada bulan Desember 2006 terhadap 
beberapa orang mahasiswa yang sudah mengikuti Praktek Penglaman Lapangan (PPL). Mereka menyatakan bahwa terdapat kesulitan dalam menerapkan teori belajar dan pembelajaran yang mereka peroleh sewaktu kuliah karena mereka kurang mendapat latihan (drill) mengajar dan pemodelan, walaupun mereka mendapt mata kuliah micro teaching. Ditambahkan oleh mahasiswa yang sudah mengikuti PPL ini bahwa mereka belum mendapatkan bagaimana cara menerapkan model-model pembelajaran itu (modeling) secara benar.

Bila ditinjau secara teori dan pendapat para pakar pendidikan, model pembelajaran sekarang ini sudah harus bergeser dari paradigma lama, teacher center ke paradigma baru, student center. Kita sudah menikmati hasil pendidikan yang dijalankan dengan pendekatan teacher center, yakni mereka kurang kreatif dan kurang mandiri. Waidi (1999) berpendapat kalau kita masih membiasakan mengajar dengan pola lama: satu arah, dogmatis, hafalan, kita akan menjadi bangsa yang "membebek," yakni bangga dan fasih menghafal teori-teori orang tapi tidak pernah menciptakannya sendiri. Selanjutnya, Ahmad Syafei dalam Dahrin (2000) berpendapat bahwa sistem pendidikan yang kurang atau tidak merangsang peserta didik untuk mengaktualisasikan potensi dirinya sudah seharusnya dihentikan, karena sistem ini akan bermuara pada kegagalan yang membawa mala petaka. Selanjutnya ditambahkan oleh

Pembelajaran yang melibatkan anak aktif berpikir adalah sangat penting dan perlu dibudayakan, dan pembelajaran yang menyebabkan anak pasif sudah seharusnya ditinggalkan atau paling tidak dikurangi. Menurut teori kerucut belajar Dale yang dikemukakan oleh Woods (1989) pembelajaran yang membuat mahasiswa pasif, kecenderungan mereka bisa mengingat materi hanya
$50 \%$, tapi kalau pembelajaran yang menuntut mahasiswa aktif, (seperti berpartisipasi dalam diskusi, menceritakan, mempresentasikan, mensimulasikan pengalaman dan melakukan sesuatu yang riil), kecenderungan mereka bisa mengingat materi yang sudah dipelajari $70 \%$ sampai $90 \%$.

Dengan pengkajian yang mendalam dan berbagai pertimbangan yang rasional dan kebutuahan sekarang dan masa datang bagi peningkatan mutu pendidikan, akhirnya, penulis berkesimpulan tidak mungkin masalah yang dikemukakan di atas dipecahkan dengan satu strategi pembelajaran. Oleh karena itu, penulis memilih multy strategy (model pembelajaran berbasis konsep, pemodelan dan metode drill) untuk pembelajaran pada mata kuliah Strategi Pembelajaran Biologi. Alasan dipilihnya strategi pembelajaran ini untuk mata kuliah Strategi Pembelajaran Biologi adalah: (1) menggunakan pendekatan konsep, hal ini sangat baik untuk memahami dan menguasai konsep-konsep dalam ilmu mendidik secara benar (untuk kompetensi pedagogik), yang sekarang ini sudah sangat berkembang, (2) menggunakan strategi pemodelan, hal ini sangat penting dilakukan supaya ada model yang bisa ditiru oleh mahasiswa, karena belajar dari model atau contoh lebih konkrit dan mudah diterapkan, (3) menggunakan metode drill, hal ini juga sangat penting untuk membentuk kecakapan atau skill mengajar calon guru, karena skill akan terbentuk melalui metode drill atau latihan.

Di samping itu, multy strategy pembelajaran ini juga sesuai dengan pemikiran Dowdeswell (1982), yang menyatakan bahwa pengajaran yang baik untuk calon guru mempunyai dua ciri: (1) mengembangkan pemahaman yang mendalam terhadap materi (konsep) tentang ilmu mendidik (pedagogik) dan (2) mengembangkan skill mengajar (teaching skill), sehingga guru mampu 
mengembangkan potensi anak didik dan membuat mereka belajar optimal.

Belajar dengan pendekatan konsep memungkinkan mudah mengerti materi dan membantu daya ingat terhadap pokok bahasan. Oleh karena itu, disarankan penggunaan pendekatan konsep dalam mengajarkan biologi dan ilmu mendidik dalam biologi (Unesco, 1986). Untuk memahami suatu konsep, siswa perlu didorong memiliki kemampuan untuk mengorganisasi, memproses, menyimpan dan mengungkapkan kembali struktur pengetahuannya atau informasi yang diperolehnya. Tanpa adanya kemampuan mengorganisasi, memproses, menyimpan, dan mengungkapkan kembali secara efisien, kemampuan mental seseorang sama halnya dengan komputer canggih yang tidak dilengkapi dengan program operasinya (Setyosari,1998). Salah satu cara penerapan pendekatan konsep adalah strategi belajar menggunakan peta konsep.

Novak melaporkan hasil penelitiannya bahwa pembuatan peta konsep (concept mapping) dapat meningkatkan pembelajaran bermakna. Di pihak lain, Alaiyemola, Jgede \& Okebukola melaporkan beberapa hasil penelitian yang menunjukkan bahwa pembuatan peta konsep (concept mapping) dapat membantu pelajar belajar lebih mendalam dan mencapai metakognisi (Okebukola, 1992). Esiobu dan Soyibo (1995) melaporkan bahwa pembuatan peta konsep dapat membuat anak belajar bermakna sehingga meningkatkan prestasi belajar secara signifikan bagi mahasiswa predegree dalam genetika dan ekologi.

Joyce et all. (1992) berpendapat bahwa pola pembelajaran untuk colon guru sangat penting menggunakan pemodelan (modeling). Strategi pemodelan ini sangat baik, karena mahasiswa calong guru dapat mencontoh atau meniru model yang sudah ada. Namun, yang penting diperhatikan adalah bagaimana menciptakan model yang baik atau tepat untuk materi dan kondisi tertentu. Inilah pekerjan guru yang sesungguhnya, yaitu merancang model pembelajaran yang ideal.

Pemodelan (modeling), artinya guru menggunakan model atau mensimulasikan model yang sudah dirancang dalam pembelajaran. Mensimulasikan model (pemodelan) sangat membantu para anak didik untuk memahami suatu konsep, baik berupa objek, ide, proses, dan peristiwa. Pemodelan juga dapat membantu mengatasi persoalan moskonsepsi (Joyce et all., 1992).

Metode drill (latihan) pada umumnya dgunakan untuk memperoleh ketangkasan atau keterampilan dari apa yang telah dipelajari. Menurut Sudjana (2002), latihan wajar digunakan untuk hal-hal yang bersifat motorik, seperti menulis, permainan, pembuatan, dan laian-lain. Kemudian, metode drill juga dapat digunakan untuk melatih kecakapan mental, melatih hubungan, tanggapan, dan sebagainya. Salah satu prinsip yang perlu diperhatikan dalam menggunakan metode drill ini adalah anak didik harus diberi pengertian yang mendalam sebelum diadalakan latihan.

Menurut teori pendidikan Gal'perin dalam Utomo dan Ruijter (1985) proses belajar dapat digambarkan secagai suatu rangkaian empat tahap, yaitu: (1) Mahasiswa berorientasi terhadap unsure-unsur ilmu yang penting, termasuk cara-cara penalaran yang khas untuk bidang ilmu tersebut. (2) Mahasiswa berlatih melakukan kegiatankegiatan bernalar melalui hubungannya antara satu objek atau kegiatan dengan yang lainnya. (3) Mahsiswa mendapat kesadaran tentang hasil belajar (umpan balik) yang telah dicapai. (4) Mahasiswa melanjutkan proses belajar dengan cara orientasi.

Dalam sebuah strategi pembelajaran adakalanya tidak cukup satu metode saja, mungkin diperlukan integrasi beberapa metode, tergantung kharakteristik 
materi, kondisi anak didik, kondisi lingkungan, sarana/prasarana yang tersedia. Biasanya untuk ilmu atau materi yang bersifat diterapkan dan keterampilan memerlukan kombinasi beberapa metode (Frazee dan Rudnitski, 1995).

Skill mengajar atau keterampilan mengajar yang dimaksudkan disini adalah keterampilan dasar mengajar. Menurut Suherman, dkk. (2003) keterampilan dasar mengajar adalah "keterampilan yang bersifat generik atau mendasar atau umum yang harus dikuasai oleh setiap guru, terlepas dari tingkat kelas dan bidang studi yang diajarkannya." Menurut Lufri (2007) terdapat sepuluh macam skill mengajar yang harus dimiliki oleh guru ataupun calon guru. Kesepuluh skill mengajar tersebut adalah: keterampilan bertanya, keterampilan memberi penguatan, keterampilan mengadakan variasi, keterampilan menjelaskan, keterampilan membuka dan menutup pelajaran, keterampilan membimbing diskusi dalam kelompok kecil, keterampilan mengelola kelas, keterampilan mengajar kelompok kecil dan perorangan, keterampilan mengembangkan dan menggunakan media dan keterampilan mengembangkan Emotional Spiritual Quotient (ESQ). Menurut Mulyasa (2005) penerapan semua keterampilan skill mengajar ini harus terintegrasi dengan baik dalam proses pembelajaran sehingga tercipta pembelajaran yang kreatif dan bermakna.

Tujuan penelitian ini adalah untuk mengungkapkan peningkatan kemampuan skill mahasiswa calon guru biologi dalam praktek mengajar melalui multy strategy pembelajaran.

\section{METODE PENELITIAN}

Metode yang dipakai dalam penelitian ini adalah metode penelitian eksperimen (pra eksperimen). Metode penelitian pra eksperimen di sini bertujuan untuk mengungkapkan kemajuan skill mengajar mahasiswa calon guru biologi dengan menggunakan multy strategy pembelajaran. Di sini tidak digunakan kelas kontrol, tetapi hanya membandingkan hasil postes dengan pretes. Nama desain ini dikenal dengan One Group Pretest-Posttest Design, seperti Gambar 2.

Pada desain ini, peneliti menggunakan satu kelas subyek penelitian. Sebelum dilakukan treatment, terlebih dahulu dilakukan pretest terhadap subyek, kemudian diberikan perlakuan dalam jangka waktu tertentu, lalu dilakukan posttest.

\begin{tabular}{|lcc|}
\multicolumn{1}{l}{ Treatment } & Pretest & Posttest \\
\hline $\mathrm{T} 1$ & & $\mathrm{X}$ \\
& $\mathrm{T} 2$ & \\
\hline
\end{tabular}

Gambar 2. One Group Pretest-Posttest Design (Fraenkel dan Wallen, 1996).

Yang menjadi populasi dalam penelitian ini (untuk implementasi multy strategy pembelajaran) adalah mahasiswa Pendidikan Biologi yang mengambil mata kuliah Strategi Pembelajaran Biologi Semester Juli-Desember 2007, yang jumlahnya 36 orang. Pada penelitian ini tidak dilakukan penarikan sampel, karena jumlah anggota populasi tidak terlalu banyak, atau dengan kata lain penelitian dilakukan terhadap populasi.

Pada penelitian ini ada dua variabel yang menjadi fokus, yaitu variabel bebas dan variabel terikat. Yang menjadi variabel bebas adalah multy strategy pembelajaran (pembelajaran berbasisi konsep, pemodelan dan metode drill). Sementara, yang menjadi variabel terikat adalah skill mengajar (skill melaksanakan pembelajaran). Data penelitian ini adalah data primer berupa skill mengajar dan sebagai sumber data adalah mahasiswa sebagai subjek penelitian. 
Alat untuk menilai skill mengajar mahasiswa calon guru atau skill melaksanakan pembelajaran diadopsi dari instrumen yang dikembangkan oleh Depdiknas (2006) untuk mensertifikasi guru, yang dikenal dengan Instrumen Penilaian Kinerja Guru 2 (IPKG 2). IPKG 2 ini digunakan untuk menilai skill (keterampilan) mengajar mahasiswa calon guru yang dijadikan subjek penelitian. Teknik analisis data yang digunakan dalam penelitian ini adalah statistik deskriptif (skor rata-rata dan persentase) guna menganalisis data skor skill praktek mengajar mahasiswa calon guru biologi. Hasil analisis ditaesirkan berdasarkan kriteria atau klasifikasi yang digunakan. Klasifikasi skor tingkatan skill prkatek mengajar diadopsi dari Buku Panduan Penilaian Program Pengalaman Lapang- an (PPL) Universitas Negeri Padang (2007), sperti berikut:

$$
\begin{aligned}
& -3,24-4,00=\text { Sangat Baik } \\
& -1,64-2,23=\text { Kurang Baik } \\
& -2,64-3,23=\text { Baik } \\
& -<1,64=\text { Tidak Baik } \\
& -2,24-2,63=\text { Cukup Baik }
\end{aligned}
$$

\section{HASIL DAN PEMBAHASAN}

\section{Hasil Penelitian}

Berikut ini adalah hasil analisis data yang diperoleh dari hasil tes awal dan teas akhir skill praktek mengajar mahasiswa yang dinilai diawal praktek mengajar dan diakhir praktek mengajar (posttest) dalam penerapan multy strategty pembelajaran, seperti terlihat pada Tebel 2 dan 3.

Tabel 2. Hasil Penilaian Pretest-Posttest Skill Mengajar mahasiswa oleh Tim Dosen

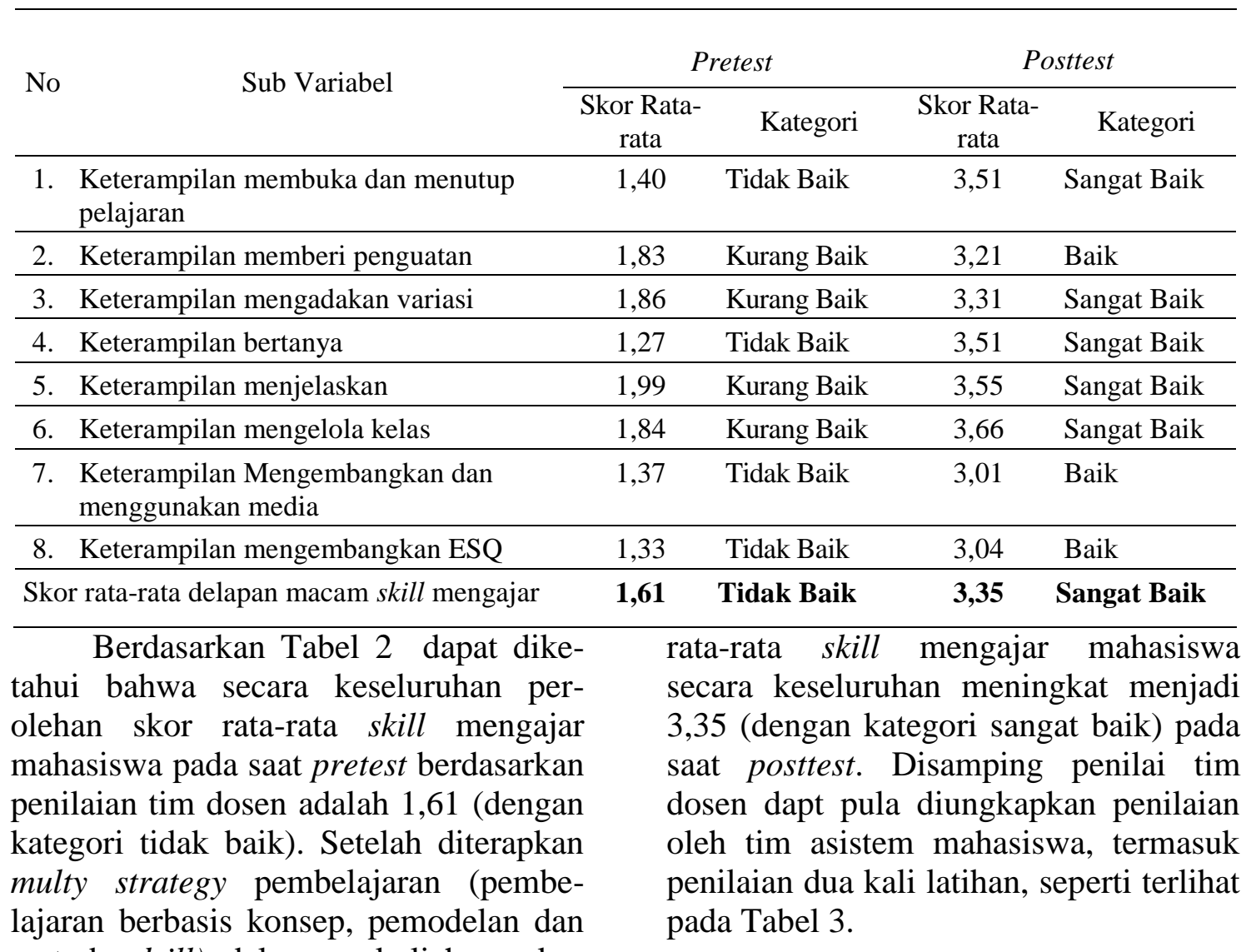


Tabel 3. Hasil Penilaian Pretest, Latihan 1, Latihan 2 dan Posttest Skill Mengajar Mahasiswa oleh Tim Asisten

\begin{tabular}{|c|c|c|c|c|c|c|c|c|c|}
\hline \multirow[t]{2}{*}{ No } & \multirow[b]{2}{*}{ Sub Variabel } & \multicolumn{2}{|c|}{ Pretest } & \multicolumn{2}{|c|}{ Latihan 1} & \multicolumn{2}{|c|}{ Latihan 2} & \multicolumn{2}{|c|}{ Posttest } \\
\hline & & $\begin{array}{c}\text { Skor } \\
\text { Rata- } \\
\text { rata }\end{array}$ & $\begin{array}{l}\text { Kete- } \\
\text { gori }\end{array}$ & $\begin{array}{l}\text { Skor } \\
\text { Rata- } \\
\text { rata }\end{array}$ & $\begin{array}{c}\text { Kate- } \\
\text { gori }\end{array}$ & $\begin{array}{c}\text { Skor } \\
\text { Rata- } \\
\text { rata }\end{array}$ & $\begin{array}{c}\text { Kate- } \\
\text { gori }\end{array}$ & $\begin{array}{c}\text { Skor } \\
\text { Rata- } \\
\text { rata }\end{array}$ & $\begin{array}{c}\text { Kate- } \\
\text { gori }\end{array}$ \\
\hline 1. & $\begin{array}{l}\text { Keterampilan } \\
\text { membuka dan } \\
\text { menutup pelajaran }\end{array}$ & 1,57 & $\begin{array}{l}\text { Tidak } \\
\text { Baik }\end{array}$ & 1,76 & $\begin{array}{l}\text { Kurang } \\
\text { Baik }\end{array}$ & 2,33 & $\begin{array}{l}\text { Cukup } \\
\text { Baik }\end{array}$ & 3,16 & Baik \\
\hline 2. & $\begin{array}{l}\text { Keterampilan } \\
\text { memberi } \\
\text { penguatan }\end{array}$ & 1,95 & $\begin{array}{l}\text { Kurang } \\
\text { Baik }\end{array}$ & 1,91 & $\begin{array}{l}\text { Kurang } \\
\text { Baik }\end{array}$ & 2,51 & $\begin{array}{l}\text { Cukup } \\
\text { Baik }\end{array}$ & 3,19 & Baik \\
\hline 3. & $\begin{array}{l}\text { Keterampilan } \\
\text { mengadakan } \\
\text { variasi }\end{array}$ & 1,68 & $\begin{array}{l}\text { Kurang } \\
\text { Baik }\end{array}$ & 1,88 & $\begin{array}{l}\text { Kurang } \\
\text { Baik }\end{array}$ & 2,47 & $\begin{array}{l}\text { Cukup } \\
\text { Baik }\end{array}$ & 3,20 & Baik \\
\hline 4. & $\begin{array}{l}\text { Keterampilan } \\
\text { bertanya }\end{array}$ & 1,34 & $\begin{array}{l}\text { Tidak } \\
\text { Baik } \\
\end{array}$ & 1,84 & $\begin{array}{l}\text { Kurang } \\
\text { Baik }\end{array}$ & 2,40 & $\begin{array}{l}\text { Cukup } \\
\text { Baik }\end{array}$ & 3,21 & Baik \\
\hline 5. & $\begin{array}{l}\text { Keterampilan } \\
\text { menjelaskan }\end{array}$ & 2,00 & $\begin{array}{l}\text { Kurang } \\
\text { Baik }\end{array}$ & 2,11 & $\begin{array}{l}\text { Kurang } \\
\text { Baik }\end{array}$ & 2,58 & $\begin{array}{l}\text { Kurang } \\
\text { Baik }\end{array}$ & 3,34 & $\begin{array}{l}\text { Sangat } \\
\text { Baik }\end{array}$ \\
\hline 6. & $\begin{array}{l}\text { Keterampilan } \\
\text { mengelola kelas }\end{array}$ & 1,70 & $\begin{array}{l}\text { Kurang } \\
\text { Baik }\end{array}$ & 1,90 & $\begin{array}{l}\text { Kurang } \\
\text { Baik } \\
\end{array}$ & 2,57 & $\begin{array}{l}\text { Cukup } \\
\text { Baik }\end{array}$ & 3,26 & $\begin{array}{l}\text { Sangat } \\
\text { Baik }\end{array}$ \\
\hline 7. & $\begin{array}{l}\text { Keterampilan } \\
\text { Mengembangkan } \\
\text { dan menggunakan } \\
\text { media }\end{array}$ & 1,52 & $\begin{array}{l}\text { Tidak } \\
\text { Baik }\end{array}$ & 1,81 & $\begin{array}{l}\text { Kurang } \\
\text { Baik }\end{array}$ & 2,39 & $\begin{array}{l}\text { Cukup } \\
\text { Baik }\end{array}$ & 3,10 & Baik \\
\hline 8. & $\begin{array}{l}\text { Keterampilan } \\
\text { mengembangkan } \\
\text { ESQ }\end{array}$ & 1,22 & $\begin{array}{l}\text { Tidak } \\
\text { Baik }\end{array}$ & 1,59 & $\begin{array}{l}\text { Tidak } \\
\text { Baik }\end{array}$ & 2,11 & $\begin{array}{l}\text { Kurang } \\
\text { Baik }\end{array}$ & 2,91 & Baik \\
\hline & $\begin{array}{l}\text { or rata-rata delapan } \\
\text { cam skill mengajar }\end{array}$ & 1,62 & $\begin{array}{l}\text { Tidak } \\
\text { Baik }\end{array}$ & 1,85 & $\begin{array}{c}\text { Kurang } \\
\text { Baik }\end{array}$ & 2,42 & $\begin{array}{c}\text { Cukup } \\
\text { Baik }\end{array}$ & 3,17 & Baik \\
\hline
\end{tabular}

Berdasarkan tabel di atas, perolehan skor rata-rata skill mengajar mahasiswa secara keseluruhan dari pengamatan tim asisten pada saat pretest adalah 1,62 (dengan kategori tidak baik). Skill mengajar mahasiswa mulai meningkat secara bertahap pada latihan 1 dan latihan 2 dengan perolehan skor rata-rata secara berurutan adalah 1,85 (dengan kategori kurang baik) dan 2,42 (dengan kategori cukup baik). Pada saat posttest mahasiswa umumnya dapat tampil praktek mengajar dengan lebih baik dengan perolehan skor rata-rata skill mengajar secara keseluruhan adalah 3,17 (dengan kategori baik).

\section{Pembahasan}

Rencana Pelaksanaan Pembelajaran yang dibuat mahasiswa diterapkan dalam latihan mengajar (feer teaching). Dalam latihan kelas dibagi atas tiga kelompok, masing masingnya 12 orang, dan masing kelompok ini dilatih oleh seorang asisten (sebagai anggota tim peneliti). Latihan mengajar pertama dianggap sebagai pretest, untuk melihat ketrampilan awal mengajar. Latihan awal ini, mereka diberi kebebasan memilih topik yang mereka sukai, de-ngan metode juga bebas, dan penampilan mereka belum dikomentari atau belum dibahas. Pertemuan berikutnya mereka mendapat kesempatan tampil berlatih masing-masing dua kali (masing-masing 15-20 menit) yang diikuti dengan diskusi atau membahas tampilan mereka masing-masing. Dari latihan inilah mereka dapat meningkatkan keterampilannya bagaimana melaksanakan proses pembelajaran secara baik menurut teori yang sudah mereka pelajari. Dari model yang dilakukan ini ternyata terdapat peningkatan keterampilan mengajar peserta 
didik yang cukup tinggi, yaitu dari kategori tidak baik menjadi kategori baik (penilaian oleh asisten mahasiswa) dan sangat baik (penilaian oleh dosen) berdasarkan kategori yang ditetapkan.

Dari perolehan skor rata-rata pretest-posttest seperti yang telah dipaparkan, terlihat bahwa skill mengajar mahasiswa dapat meningkat. Peningkatan ini berlaku baik dari hasil pengamatan tim dosen maupun dari hasil pengamatan tim asisten. Peningkatan Skill mengajar mahasiswa ini tidak terlepas dari strategi pembelajaran yang dipilihkan dan diterapkan untuk memenuhi tuntutan penguasaan materi dan pelaksanaan perkuliahan

Pada saat perkuliahan mahasiswa dibekali dengan materi yang berkaitan dengan ilmu mendidik seperti pengenalan berbagai macam pendekatan dalam pembelajaran, metode dan model pembelajaran serta keterampilan dasar mengajar yang dapat menunjang skill mengajar mahasiswa. Dalam menjelaskan materi tim dosen lebih mengarahkan mahasiswa untuk belajar dengan cara memahami konsep, misalnya dengan mengemukakan contoh-contoh yang konkrit dari penerapan materi tersebut dan juga meminta mahasiswa mampu mengungkapkan contoh-contoh yang lain. Hal ini sesuai dengan pendapat Mulyati (2000) bahwa melatih mahasiswa untuk mampu mengungkapkan contoh lain dengan baik akan menghindarkan mahasiswa dari penguasaan materi secara verbalisme/ hafalan dan transfer belajar dapat tejadi melalui pemahaman sehingga diharapkan efektifitas kegiatan pembelajaran dapat terjadi. Selain itu selama perkuliahan, dalam kegiatan diskusi mahasiswa diarahkan untuk menjawab pertanyaan berbasis konsep yang telah disusun pada bahan ajar dan mahasiswa diminta mempresentasikan materi diskusi dalam bentuk peta konsep. Penggunaan peta konsep dapat memudahkan mahasiswa untuk memahami materi dalam bentuk yang lebih sederhana. Penguasaan mahasiswa terhadap teori dalam ilmu mendidik ini sangat penting, karena menurut Rustaman, dkk. (2003) untuk dapat menerapkan suatu teknik/ keterampilan secara tepat dan benar, seseorang terlebih dahulu harus mengetahui teori bagaimana keterampilan tersebut diwujudkan.

Pembelajaran dengan pemodelan (modelling) dilakukan pada waktu perkuliahan teori ataupun pada saat latihan/ praktek. Pemodelan dilakukan baik oleh tim dosen, tim asisten dan juga pemodelan melalui VCD. Dengan adanya pemodelan dapat membuat mahasiswa memahami konsep dengan lebih baik dan dapat menghindarkan miskonsepsi terhadap materi yang dipelajari. Dengan pembelajaran dengan pemodelan dan pembelajaran berbasis konsep yang dilakukan dapat memenuhi tahapan kognitif dalam memperoleh Skill mengajar.

Aplikasi dari teori mendidik yang dipelajari dari perkuliahan dipraktekkan mahasiswa sewaktu latihan/praktek mengajar. Setelah mahasiswa tampil praktek mengajar, diberikan feedback/ umpan balik dengan cara mendiskusikan penampilan tersebut. Menurut Nur, dkk. (2005) umpan balik memiliki arti penting, karena tanpa pengetahuan akan latihan yang telah dilakukan, baik berupa tindakan yang sudah benar ataupun yang masih perlu diperbaiki, latihan akan memiliki efek sangat kecil bagi peserta didik. Hal ini terbukti dengan meningkatnya skor rata-rata skill mengajar yang diperoleh mahasiswa untuk tiap kali tampil praktek mengajar (latihan 1, latihan 2, dan posttest). Berikut ini akan dijelaskan peningkatan masing-masing sub variabel skill mengajar mahasiswa berdasarkan data dan pengamatan yang dilakukan selama penelitian. 


\section{PENUTUP}

\section{Kesimpulan}

Terdapat peningkatan ketrampilan skill mengjar mahasiswa calon guru biologi (skill melaksanakan pembelajaran) melalui multy strategy pembelajaran (pembelajaran berbasis konsep, pemodelan dan teknik drill) yang diterapkan yang diterapkan dalam mata kuliah Strategi Pembelajaran Biologi. Skor akhir yang diperoleh menunjukkan ketrampilan (skill) mengajar mahasiswa calon guru berada pada kategori baik (menurut penilaian tim asisten mahasiswa) dan sangat baik (menurut penilaian tim dosen), sementara skor awal berada pada kategori tidak baik.

\section{DAFTAR RUJUKAN}

Dahrin, D. 2000. Memperbaiki Kinerja Pendidikan Nasional Secara Komprehensif: Transformasi Pendidikan. Forum Rektor Indonesia, 1 (5): 22-28.

Dwiyogo, W. D. 1997. Teaching Thinking and Problem Solving. Jurnal Teknologi Pembelajaran: Teori dan Penelitian, 5 (1): 13-21.

Dowdeswell, W.H. 1982. Teaching and Learning Biology. Austrlia: Heinemann Educational Books.

Esiobu, G.O. \& Soyibo, K. 1995. Effects of Concept and Vee Mapping under Three Learning Modes on Students' Cognitive Achievement in Ecology and Genetics. Journal of Research in Science Teaching, 32 (9): 971-995.

Fraenkel, J.R. \& Wallen, N.E. 1996. How to Design and Evaluate Research in Education. Ed. $3^{\text {th }}$ New York: McGraw-Hill, Inc.

Frazee, B.M. dan Rudnitski, R.A. 1995. Integrated Teaching Methods:

\section{Saran}

Mengingat dampak positif yang ditimbulkan multy strategy pembelajaran yang dikembangkan terhadap peningkatan skill calon guru dalam pelaksanaan pembelajaran, maka pantaslah disarankan kepada: (1) Tim matakuliah Strategi Pembelajaran Biologi untuk menjadikan multy strategy ini sebagai salah satu alternatif untuk meningkatkan mutu pembelajaran Strategi Pembelajaran Biologi dan (2) Tim matakuliah Strategi Pembelajaran bidang studi lain, seprti Matematika, Fisika, Kimia dan sebagainya dapat mengadopsi model ini untuk meningkatkan mutu pembelajarannya.

Theory, Classroom Applications, and Field-Based Connections. Washington: Delmar Publihers.

Hasibuan,J.J.\& Mudjiono. 2006. Proses Belajar Mengajar. Bandung : PT. Remaja Rosdakarya.

Joyce, B., Weil, M. dan Showwers, B. 1992. Models of Teaching. Ed. ${ }^{4 \text { th }}$ London: Allyn and Bacon.

Lufri . 2007. Strategi Pembelajaran Biologi: Teori, Praktek dan Penelitian. Padang: UNP Press.

Mulyasa, E. 2005. Menjadi Guru Profesional. Bandung: PT. Remaja Rosdakarya.

Mulyati, Sri. 2000. Cara Menguasai Konsep, Defenisi, dan Teorema Dalam Geometri. Forum Pendidikan. 6(2): 79-81.

Nggermanto, Agus. 2005. Quantum Quotient. Bandung: Penerbit Nuansa.

Nur, M. \& Wikandari, P.R.. 2004. Pengajaran Berpusat Kepada Siswa dan Pendekatan Kons- 
truktivis dalam Pengajaran. Edisi 3. Surabaya: Universitas Negeri Surabaya.

Okebukola, P.A. 1992. Can Good Concept Mappers be Good Problem Solvers in Science? Research in Science \& Technological Education, 10 (2): 153-170.

Rustaman, dkk. 2003. Strategi Belajar Mengajar Biologi. Bandung: Universitas Pendidikan Indonesia.

Sayibo, K. 1995. Using Concept Maps to Analize Textbook Presentation of Respiration. The American Biology Teacher, 57 (6): 344-351.

Setyosari, P. 1998. Pengajaran Pemerolehan Konsep. Sumber Belajar, (5): 57-68.

Sudjana, N. 2002. Dasar-dasar Proses Belajar Mengajar. Bandung: Sinar baru Algensindo.

Indeks

guru $1,16,17,18,19,22$ mahasiswa.. 1, 16, 17, 18, 19, 20, 21, 22 model $16,17,21,22$

Pembelajaran $1,16,19,22,23$
Suherman, dkk. 2003. Strategi Pembelajaran Matematika Kontemporer. Bandung: Universitas Pendidikan Indonesia.

Unit Program Pengalaman Lapangan. 2007. Buku Penilaian Program Pengalaman Lapangan Kependidikan. Padang: Universitas Negeri Padang.

UNESCO. 1986. Unesco Handbook for Biology Teachers in Asia. New Delhi: Pearl Offset Press Pvt. Ltd.

Utomo, T. Dan Ruijter, K. 1985. Peningkatan dan Pengembangan pendidikan. Jakarta: Gramedia

Waidi. 1999. Pemberdayaan Subyek Didik. Suara Soedirman, 2 (3): 1718.

Woods, D.R. 1989. Developing Students' Problem-Solving Skills. Journal of College Science Teaching (JCST), November: 108-110.

pendidikan $1,16,18,24$

skill $1,16,17,18,19,20,21,22$

Strategi $1,16,17,19,22,23$ 